\title{
Revolutionary Gender Equality: The Dimensions and Limits of Female Emancipation in the Sandinista Revolution
}

Julia Heaton

The Nicaraguan Sandinista Revolution of the 1970s was notable not just for its political success, but also for the mass participation of women in the movement. The social space of the revolution provided an opportunity to re-structure gender relations and challenge the traditional conceptions of women held in Nicaraguan society. However, this experience of gender equality was primarily limited to the revolutionary period, as the Sandinista government did not work to continue the process of female emancipation once in power.

Revolutionary periods are times of upheaval, creating the potential for turnover of both institutions and ideologies. Even if a revolution is primarily political in nature, the climate of change that the revolution creates can foster both political and social transformation. ${ }^{1}$ Founded in 1961, the Nicaraguan Sandinista Liberation Front (FSLN) movement grew in power over the 1970s, culminating in 1979 with the Front's successful overthrow of the long-standing Somoza dictatorial dynasty. ${ }^{2}$ The FSLN revolution was unique not only in its success but also in the unprecedented number of women who participated in the process of the revolution and the subsequently established FLSN government at various levels of power. ${ }^{3}$ The entry of women into the political arena was revolutionary not only in altering the political experience of Nicaraguan women who participated, but also in challenging the nation's long-held perceptions of women more broadly. Nicaraguan women took an active role in the FSLN movement despite significant structural and notional barriers to their involvement. This participation challenged conceptions of women's abilities and place in society. However, this change in mindset was limited, as seen in the failure of the FSLN to pursue complete female emancipation after taking power.

The confinement of Nicaraguan women to the domestic sphere prior to the revolution served not only to physically segregate women from political activities in public spaces, but also placed a burden on women as the group bearing the primary responsibility for the domestic tasks of a household. ${ }^{4}$ As such, when a woman entered political activities, she faced not only the difficulties inherent in an unfamiliar experience, but also the challenge of balancing her assumed responsibilities within the home with her new 
involvement outside of it, as well as feelings of guilt for her neglect of these domestic duties by dividing her time between spheres. In her memoir The Country Under My Skin, female revolutionary Gioconda Belli expressed her concern that her involvement with the FSLN might "destro[y] [her] home in pursuit of [her] dreams". 5 The guilt of dividing time between family and revolutionary activities was a predominantly female preoccupation, ${ }^{6}$ as evidenced by Belli's expressed fear that she had no right "as a mother" to partake in the risks inherent in revolutionary involvement, despite the ability of her husband to assume care of her daughters if the need arose. ${ }^{7}$

Women who elected to participate in revolutionary activities struggled not only against their own internalized apprehensions, but also against clear objections from family members. Diana Espinoza, a working-class woman who joined the revolution at a young age, was told by her father that her participation arose from naïvety, and that revolutionary leaders were "taking advantage of [her] innocence". 8 Assumptions of female political ignorance were capable of fostering female doubt in their own actions as well as eroding the authority of women who chose to be visibly politically active. Spousal opposition to female revolutionary involvement was also very common. The new aspirations of FSLN women often made them targets of sexual jealousy from husbands who did not share their wives' political convictions and resented their revolutionary involvement for pulling them away from the home. ${ }^{9}$ Both Gioconda Belli and Nora Astorga were prominent female FSLN members who had difficulty maintaining the harmonies of their respective marriages as their revolutionary involvement increased. Both women separated from their non-revolutionary husbands in the early years of the movement, and gained greater personal freedom in doing so. Belli likened her freedom as a single woman to that of "a mare set loose from the corral", and Astorga identified the break up of her marriage as a catalyst for her full commitment to the FSLN. ${ }^{11}$ Increased rates of divorce during Nicaragua's revolutionary years and in the early days of FSLN rule suggest that Belli and Astorga's experiences were not isolated phenomena. ${ }^{12}$

Traditional family structure and roles often defined the participation of older women. Many of the women who joined the FSLN movement were past the age of active combat, and were instead drawn in by their children's participation on the battlefield. ${ }^{13}$ Older women participated at a higher rate than older men, suggesting that the maternal role served as a direct motivator for involvement. ${ }^{14}$ Zulema Baltodano was a mother of nine children, all of whom became involved with the FSLN at some point during the revolution. She was initially fearful at the prospect of her children's involvement, worried that her children "would just become more martyrs", leaving her alone and grieving without having achieved notable political success. ${ }^{15}$ The large number of young Nicaraguans in the FSLN movement had the effect of creating a large group of 
fearful mothers, emotionally tied to the political process by the choices of their offspring. This current of fear among women throughout Nicaragua allowed the creation of a unified community of mothers affected by the revolution, which shaped the women's disparate worry and grief into a concrete political force. This organization was seen most clearly in the formation of The Mothers of Heroes and Martyrs group in the 1980s under the FSLN government, but bodies such as this one gained much of their momentum and membership during the years of the guerrilla struggle. ${ }^{16}$ The experience of motherhood during the years of the FSLN revolution served as a political gateway, as many younger participants were able to effectively communicate the goals and ideas of the FSLN movement to their mothers, and thus brought them into alignment with the Sandinista cause. Zulema Baltodano's concern over her children's well-being in the FSLN led her to learn more about the movement itself, and she found that "being more politically aware...helped" her to endure periods of uncertainty and worry, as she was able to empathize with the ideas for which her children risked their lives. ${ }^{17}$ Though the mobilization of these women was a step towards equality in political participation in terms of the numbers of women brought into the movement, the revolutionary experience of older women was largely bound by the constraints of traditional gender roles. ${ }^{18}$ Women who fit within a conventional image of suffering motherhood were glorified for their sacrifices, and while this political attention may have empowered women who were accustomed to having their voices silenced in political processes, it did not challenge or alter the social role of women in the nation. The organization of mothers as a primary form of female involvement further reinforced domesticity and maternity as intrinsic to female identity in Nicaragua. This pattern of involvement allowed political action to occur as a new manifestation of the traditional female childcare role. $^{19}$

The deep intertwining of the maternal role into revolutionary activity was a phenomenon mostly experienced by older women. Women who were not yet of the age to have politically active children participated in a way that was more separated from their familial role, but still experienced the revolution in a form impacted by gender. The almost complete exclusion of Nicaraguan women from the political arena before the rise of the FSLN meant that the process of politics in Nicaragua, as in many countries, was developed around uncontested male domination. Even if barriers to female political participation were removed or reduced by FSLN policies, the political space had been shaped by the existence of these barriers. As a result, women who involved themselves in politics during the period of the FSLN revolution may have found their initial political experience to be exclusionary, and may have experienced male hostility, aggression, or ignorance. ${ }^{20}$ Monica Baltodano, a commander of FSLN guerrilla forces, found that "male chauvinism" and "sexist attitudes" were prevalent among her male comrades. ${ }^{21}$ 
Although some female participants were held back from pursuing domestic tasks or moving beyond messenger roles, ${ }^{22}$ women also fought as troops in the Sandinista army and rose to take leadership positions, making up more than a third of FSLN leaders at the time of Somoza's overthrow. ${ }^{23}$ Gioconda Belli describes how "being an upper-class woman was an ideal alibi", allowing her to carry out FSLN work without suspicion, as she was protected as a "daughte[r] of the bourgeoisie". ${ }^{24}$ Nora Astorga accomplished the capture and assassinatio of a Somoza general by using her own female sexuality to lure him into her home. ${ }^{25}$ The assumptions of innocence and naïvety often imposed on members of the female sex were manipulated by politically active women and allowed them to perform tasks that could not be carried out by men. Women also fought alongside male revolutionaries in active FSLN battles, though the entry of females into combat was slower than the entry of women as messengers or support workers. ${ }^{26}$ More than the streets or community spaces where communication and recruitment work were conducted, the battlefield had long been established as a traditionally male space. The inclusion of female soldiers brought women into a space that had long held a key role in shaping male identity. ${ }^{27}$ The shared military experience of men and women in the FSLN movement was integral in fostering what FSLN soldier Ana Julia Guido calls the "incredible solidarity" that crossed gender lines during the revolutionary years. ${ }^{28}$

Female political participation in any form represented a break from the traditional social role women in Nicaragua were expected to fill. ${ }^{29}$ Additionally, the participation of women alongside men in both organizational and combat work moved male-female relations into new environments, forcing both genders to alter, to some degree, the ways in which they interacted with each other. ${ }^{30}$ Belli found that women were no longer viewed as "delicate flowers or helpless beings" once they had proven their capabilities during the revolution, and that mass female involvement in the FSLN movement was a necessary step in women being conceived of as having "adult status". ${ }^{31}$ Leticia Herrera, a guerrilla commander, stated that women "acquired tremendous moral authority" by their revolutionary actions. These actions, said Herrera, necessitated male "respect" for women, and made it more difficult for men to justify female "mistreat[ment]", now that they had changed in status from mere women to fellow combatants. ${ }^{32}$ Monica Baltodano stated that battles of sexism were won when "women comrades demonstrat[ed] their ability and their resistance". 33

The movement towards gender equality in the revolutionary period was a situation allowed for by the unique environment of guerrilla warfare and political change. Nora Astorga described the revolutionary period as one in which "the boundaries of normal life were broken". ${ }^{34}$ The intensity of the Sandinista project was such that it was able to bend the social boundaries of peacetime, and allowed a re-configuration of gender 
dynamics and identity. As one female commander remarked, "anything, even the role of women-so deeply rooted-can change" in such dynamic circumstances. ${ }^{35}$ However, though the chaos of conflict spurred situational change, its ability to solve all of the complexities of gender dynamics was limited. ${ }^{36}$

Women who entered the public sphere as political actors often struggled to be seen as revolutionaries or politicians separate from their female bodies and identities. Sexual abuse and harassment were common within the FSLN, and male perpetrators rarely faced disciplinary consequences. ${ }^{37}$ Women were aggressively sexualized by their male peers and simultaneously persecuted for their own sexual choices. In Belli's revolutionary experience she was both "pounce[d]" upon by political leaders fuelled by an "explosive mix of of power and sex", and coerced by the FSLN to end a personal relationship on the "insulting notion" that her own sexual choices could potentially compromise the strength of the revolution. ${ }^{38}$ The FSLN did not intervene this way in the sexual relationships of male members, and experiences of sexual assault and harassment appear much more frequently, if not exclusively, in female narratives of the revolutionary experience.

The mass participation of women in the revolution did not go unnoticed by the visual and cultural media of the period, and these sources reveal popular conceptions of female revolutionaries. Carlos Mejia Godoy's song "Girl of the Sandinist Front" presented a romanticized image of female militants, describing the "long flowing hair" of an unnamed "simple girl" in the FSLN ranks. Though Godoy glorified female commitment to the nation, he framed this commitment as "another relation", suggesting women pursued a hopeful future for Nicaragua in the same way they might have pursued a love interest. Godoy simplified female political activism into a romantic endeavour, and in doing so ignored the legitimate ideological commitment and dramatic sacrifices of many female participants to the Sandinista cause. Godoy's closing line "girl, you're a woman now" emphasizes the role revolutionary action played in legitimizing women as capable adults. ${ }^{39}$ A photograph of a smiling young woman breast-feeding her child while carrying a machine gun over her shoulder became one of the most circulated images of the revolution, and was used as an example of complete commitment to the Sandinista cause. ${ }^{40}$ The woman in this picture was held up as an example for her ability to exhibit simultaneous loyalty to her country and to her domestic duties. ${ }^{41}$ Though the exemplification of a female soldier proved public acceptance of female participation, the duality of this popular image revealed the continued expectation of women to fill certain familial roles. Posters created by the FSLN government continued to present the idealized Sandinista woman as both politically and domestically involved, showing female militants holding both infants and weapons while surrounded by happy 
children. ${ }^{42}$ These representations served to politicize the traditional social positions of women but did not make an effort to move away from these set roles.$^{43}$

One obstacle to the equality of Nicaraguan women in the 1970s was Machismo, an attitude of masculine pride that glorified character traits traditionally associated with the male gender.. Machismo in Nicaragua established men as actors and decision makers, while women remained subjects over which men could assert their power. ${ }^{44}$ As a deepset and long-held view, machismo was not easily shaken by the period of FSLN activism. Nora Astorga testified that machismo "[went] beyond" opportunities for female participation, and persisted as an ideology underlying both male and female actions. ${ }^{45}$ Because of its solid establishment in Nicaraguan culture, machismo was often perpetrated unconsciously, so that even women who wished to distance themselves from the mindset may have taught it to their sons or daughters without realizing they were doing so ${ }^{46}$ Gioconda Belli attested that women experienced subordination in a way that taught them it was "an inherent part of being a woman". ${ }^{47}$ This learned subordination often held women back from pressing for complete equality, leading to female perpetration of gender disparity.

The path to gender equality in Nicaragua was altered when the Sandinistas overthrew the Nicaraguan government in 1979. The transformation of the FSLN from revolutionary force to governing body required a change to the structure of female political action, as the focus was no longer on female entry into the political arena but rather on how to incorporate women into the political agenda. ${ }^{49}$ Nicaraguan women had established their worth to the FSLN revolution in helping the party to rise up and take power, and though the FSLN still needed the support of women as part of their democratic base, female emancipation required a movement of women from source of political support to repository of political priority. ${ }^{50}$ The mobilization of women had been beneficial in empowering involved women and, to some extent, challenging popular perceptions, but political mobilization alone was not able to serve all of the goals of Nicaraguan women, and so was not an end in itself. ${ }^{51}$ The Sandinista Revolution simultaneously brought the FSLN to power and brought women into the political sphere, but under the FSLN government, women had to contend for their rights and voices to be recognized in the newly established regime.

The struggle against Somoza collectivized a diverse group of Nicaraguans as opposition to the dictatorship served as a unifying goal. This clear directionality merged the goals of individual revolutionaries and allowed for the subjugation of personal identities to the larger aims of the movement. ${ }^{52}$ The emphasis on national unity prioritized Nicaraguan identity over gender identity, so that for many women female interests were sidelined until the popular goal of overthrowing Somoza had been achieved. The collectivization of interests fostered an androgynous identity, and a certain degree of 
homogeneity was inherent in the unity that was crucial to the success of the movement. ${ }^{53}$ As a national movement, the FSLN needed to define a national identity, necessitating the emphasis of some demographics over others. ${ }^{54}$ Though women made up a significant proportion of the FSLN, the identity reflected, as is often the case, the powerful majority. Though women were not a significant minority within the FSLN, women's interests came to be viewed as minority interests as they were not strongly incorporated into the FSLN's primary vision.

Life in FSLN Nicaragua was a disappointment to many of the women who had felt liberated by the revolution. Belli likened her entrance into Nicaragua's capital, Managua, after the FSLN victory to the "joy after pain" of childbirth, and rejoiced at the birth of a new era for Nicaragua. ${ }^{55}$ However, this joy was short lived for Belli and many of the other women who helped to bring the new Nicaragua into being. Women, who had fought alongside men for the duration of the conflict and, in Belli's words, "proven themselves to be as able fighters as men" were, after the FSLN takeover, first trained separately from male soldiers and then barred from active service altogether and limited to service in administrative posts. ${ }^{56}$ In theory, the Sandinistas supported gender equality as a key element of complete social equality, but events after the FSLN took power suggest that there was a gap between ideological commitment and effective action on the issue. ${ }^{57}$ Female Sandinistas testified the existence of men whose public political lives clashed with their abuse of wives and children at home. ${ }^{58}$ The disparity between official FSLN stance and the machismo or sexist attitudes still held by many FLSN politicians prevented the Sandinista vision of gender equality from becoming a reality. In this way, the establishment of the FSLN government did not create a new model of gender relations, but instead established a new patriarchy in place of the one that had been overthrown. ${ }^{59}$

The Sandinista revolution created the conditions that allowed women to break with political tradition, and as a result the emancipation of women in the 1970s and 1980s in Nicaragua was inseparable from the history and existence of the FSLN movement. ${ }^{60}$ From 1979 on, however, the FSLN that had allowed for mass female political mobilization became a force of resistance to feminist demands. ${ }^{18}$ AMNLAE (Luisa Amanda Espinoza Association of Nicaraguan Women), the Sandinista organization tasked with advocating for female rights and equality in FSLN Nicaragua, adopted the slogan "No revolution without women's emancipation: no emancipation without revolution". ${ }^{61}$ Though this line emphasized the importance of gender reform to the revolutionary process, it also highlighted the dependency of the women's movement upon the FSLN. This dependency justified the FSLN leadership's prioritization of the revolutionary agenda almost completely over the feminist one. ${ }^{62}$ The framing of feminist issues as separate from the issues of revolutionary survival was presented as a 
separation of cultural versus political considerations. This separation revealed the continued existence of the bias of female as apolitical, and demonstrated that despite the significant movement of women into the political sphere during the revolution, women had not been successful in proving their place as political actors. ${ }^{63}$ While the revolution was a public issue of relevance to the entire population, many of the changes advocated for by feminist reformers, such as sexual rights or reform to domestic violence laws, were viewed as private issues, despite the necessity of achieving equality within the home in order to achieve complete equality in politics. The conception of feminist issues as private and individual and the emphasis on a national non-gendered revolutionary identity allowed female interests to be framed as minority, special-interest causes, thus justifying their de-prioritization.

The gender consciousness that arose from political action spurred some women to advocate for feminist legislation from the FSLN. Female revolutionary Vidaluz Meneses testified that the most important result of female mobilization is that women "began to see [them]selves as women". 64 However, feminist reforms were not incorporated into the primary accepted view of FSLN progress, and so women advocating for causes that had been ignored by the popular Sandinista vision were considered divisive and disruptive to the movement. The exclusion of feminist reforms from the FSLN's top priorities taught women not to advocate for many of the problems that affected them, leading to a current of female self-silencing that further slowed the progress of women's emancipation. ${ }^{65}$ Identifying women's issues as minority issues and thus of lower importance stymied the path to emancipation and thus prevented the achievement of complete gender equality, an end that certainly could have been viewed as a majority issue on basis of its impact on the entirety of Nicaragua.

Despite reluctance to pursue all of the reforms necessary for female equality, the FSLN recognized the importance of female support to its continued existence and success. Female political action was supported within the FSLN insofar as it was beneficial to the overall goals of the movement. ${ }^{66}$ This qualified support for women's rights and advocacy manifested in the pursuit of reforms that benefitted women without fundamentally altering or challenging their social position. For example, the FSLN's literacy campaign improved quality of life for many Nicaraguan women by increasing their awareness of financial processes, nutritional information, and improving their ability to participate in business, but though this campaign benefitted the female population, it was not a feminist reform. Actions such as the literacy campaign were pursued as beneficial to all Nicaraguans, and though this included women, the place of women within society was not the target of the reform. The Nicaraguan state was thus able to exist as female-supported without being feminist, as the government pursued female benefit without advancing the cause of female emancipation. ${ }^{67}$ 
The first years of the FSLN government did include laws directly targeted at women, but these were fit into a set vision of female identity and role. The Nurturing Law was introduced by the FSLN in 1982. It imposed equal parental responsibilities and obligation of domestic duties on men and women. ${ }^{68}$ The Nurturing Law was one of the FSLN's most direct advances toward equality between men and women within the private sphere, but other paths to equality were not pursued. Despite being legal, contraceptives were difficult for many Nicaraguan women to obtain in the early 1980s, and stigma continued to exist around their use. ${ }^{69}$ No legislation was issued regarding domestic violence, rape, or sexual harassment, and efforts to decriminalize abortion were met with complete resistance. ${ }^{70}$ The passing of the Nurturing Law showed support for women within the role of mother and homemaker, while lack of action on providing women with access to contraceptives or abortions showed a cultural hesitancy to enact legislation that ran contrary to the maternal role. The failure of the FSLN to address issues of violence against women suggests that the primary motivation of reforms directed at women was not the improvement of life for women, but rather that the pattern of these reforms was determined by the degree to which the reforms contributed to the stability of the nation. Supporting women in their role within traditional family structures was beneficial to overall social stability, while empowering women to break from this role, or challenging male-female relations within the home were not, and so legislation to these ends was not pursued.

The approach to women in FSLN legislation was important because the grassroots nature of Nicaragua's democracy in the late $1970 \mathrm{~s}$ and into the $1980 \mathrm{~s}$ meant that the government's laws were closely connected to the views of the Nicaraguan people, and both affected and reflected prevailing social attitudes. ${ }^{71}$ Beyond reinforcement of the maternal role, attitudes towards proper female conduct and identity were exhibited in the Provisional Media Law, passed by the FSLN shortly after coming to power in 1979 . The law banned the use of commercialized images of women's bodies, and condemned the sexual exploitation of women by the media. ${ }^{72}$ This law was celebrated by feminist reformers who hoped its early introduction demonstrated a commitment by the FSLN to female-directed reforms. However, coupling the passage of the Provisional Media Law with the lack of FSLN legislation regarding rape or domestic abuse shows that the FSLN's top priority was not in fact the freedom of women from gender-based oppression. As above, the Provisional Media Law served the dual purpose of maintaining female support for the government while aligning with FSLN political objectives. The FSLN had nothing to lose in criminalizing female sexualization in advertising, and in doing so could promote the wholesome domestic female identity that it had come to perpetrate as the primary acceptable form of female expression. 
Despite the fact that over a third of FSLN leaders in the revolutionary period were female,${ }^{73}$ the national directorate of the FSLN was entirely male throughout their entire governance period. ${ }^{74}$ Doris Tijerino, a revolutionary commander who moved into administrative leadership after the fall of Somoza, attested that the FSLN made it difficult for women to rise to leadership roles, and that the women who did secure these positions did so at "enormous personal sacrifice" ${ }^{75}$ The lack of female representation at the top of the FSLN limited options for effective political advocacy of women's issues and further decreased the chance of these issues being included in the FSLN's primary agenda.

The transition of the Sandinistas from revolutionary force to governing body required a change of focus from challenging the political situation to maintaining stability. During the revolution, all contributions to the Sandinista effort were needed and appreciated, and so the role of women was allowed to change, as doing so was of benefit to the movement. Once the FSLN had taken control of the government, however, there was less of a need for popular mobilization, and there was no longer an infinite supply of roles. While women had been accepted into male spaces in administration and the military during the FSLN struggle, their place in government and in the army was contested once the revolution was completed. ${ }^{77}$ Nicaragua's change in political regime did not necessarily entail a change in methods of conducting politics, and established hierarchical patterns of power were quick to re-emerge. The movement from popular to sustained organization limited the number of available power positions and increased the potential for marginalization within the movement. ${ }^{79}$ The establishment of the FSLN government replaced the gender equality experienced by some women during the insurrection with a patriarchal government that caused gender relations to resemble those that existed before the revolution more closely than the gender relations of the revolutionary period. ${ }^{80}$

When Nicaraugua's political situation changed again a few years after the Sandinista's government takeover, the place of women in the country's political agenda was altered again. Beginning in 1981, the Contra war, a counter-revolutionary effort that attempted to destabilize the Sandinista government further decreased the importance of women's issues in the minds of many FSLN politicians. ${ }^{81}$ The Contra war created economic stress that detracted from governmental motivation to pursue social reforms, and challenges to FSLN power made the government less likely to pursue feminist actions that may have been unpopular with some of their political base. ${ }^{82}$ Belli testified that the war environment, unlike the atmosphere of the guerrilla revolution, served to further alienate women from politics as an FSLN leadership body of "proud, hardhearted men" responded to the Contra threat in a "testosterone-driven manner". ${ }^{83}$ The counterrevolution was a political stressor that forced itself into a high position on the list of 
FSLN priorities, further demoting the importance of woman's rights and feminist reforms. $^{84}$

The Sandinista Liberation Front in the 1970s incorporated women into the movement in ways Nicaraguan women had not previously experienced. Female political mobilization was both groundbreaking and challenging, as it ran up against long-standing conceptions of female identity and societal role. The involvement of women in the FSLN presented a challenge to perceptions of women in the period, but despite these challenges, gender biased conceptions of women survived the events of the revolution. The incomplete ideological emancipation of women manifested itself under the FSLN government, which supported women without making a full commitment to gender equality. Nicaraguan women were politically mobilized by the FSLN movement, and though significant, this period of mobilization did not result in the achievement of complete equality for women. 


\section{$\underline{\text { References }}$}

1. Jane S. Jaquette, The Women's Movement in Latin America: Feminism and the Transition to Democracy (Winchester: Unwin Hyman, 1989), 5.

2. Benjamin Keen and Mark Wasserman, A History of Latin America (Boston: Houghton Mifflin

Company, 1988), 479-484.

3. Karen Kampwirth, "Confronting Adversity with Experience: The Emergence of Feminism in Nicaragua,” Social Politics 3, no. 2 (1996): 137.

4. Linda L. Reif, "Women in Latin American Guerrilla Movements: A Comparative Perspective," Comparative Politics 8, no. 2 (1986): 148.

5.Gioconda Belli, The Country Under My Skin (New York: Alfred A. Knopf, 2002), 131.

6. Linda L. Reif, "Women in Latin American Guerrilla Movements," 162.

Belli, The Country Under My Skin, 78.

7. Belli, The Country Under My Skin, 78.

8. Margaret Randall, Sandino's Daughters Revisited: Feminism in Nicaragua (Vancouver: New Star Books, 1994), 94.

9. Lucinda Broadbent, Helen Collinson, Daphne Davies, Elaine Ginsburg, Clare Nuttall, and Jean Somers,

Women and Revolution in Nicaragua. ed. Helen Collinson (London: Zed Books, 1990), 11.

10. Belli, The Country Under My Skin, 76.

11. "Nora Astorga In Her Own Words," Revista Envio, no. 82 (1985): 4-5.

12. Irene Campos Carr, "Women's Voices Grow Stronger: Politics and Feminism in Latin America," NWSA Journal 2, no. 3 (1990): 455.

13. Margaret Randall, Sandino's Daughters (Vancouver: New Star Books, 1981): 62-65.

14. Randall, Sandino's Daughters Revisited, 18.

15. Randall, Sandino's Daughters, 63-64.

16. Kampwirth, "Confronting Adversity with Experience," 142.

17. Randall, Sandino's Daughters, 66.

18. Kampwirth, "Confronting Adversity with Experience," 142.

19. Ibid.

20. Reif, "Women in Latin American Guerrilla Movements," 150.

21. Randall, Sandino's Daughters, 66.

22. Ibid.

23. Kampwirth, "Confronting Adversity with Experience," 139.

24. Belli, The Country Under My Skin, 40 and 54-55.

25. "Nora Astorga In Her Own Words," 6-7.

26. Reif, "Women in Latin American Guerrilla Movements," 159.

27. Ariana E. Vigal, "Gender, Difference, and the FSLN Insurrection” in War Echoes: Gender and

Militarization in U.S. Latina/o Cultural Production. (New Brunswick: Rutgers University Press, 2014 ), 34.

28. Randall, Sandino's Daughters, 131.

29. Randall, Sandino's Daughters Revisited, 5.

30. Kampwirth, "Confronting Adversity with Experience," 140.

31. Belli, The Country Under My Skin, 89.

32. Randall, Sandino's Daughters, 56.

33. Ibid., 66.

34. "Nora Astorga In Her Own Words," 8.

35. Randall, Sandino's Daughters, 57.

36. Vigal, War Echoes, 34.

37. Nadine Jubb, "Love, Family Values and Reconciliation for All, but What about Rights, Justice and Citizenship for Women? The FSLN, the Women's Movement, and Violence against Women in Nicaragua," Bulletin of Latin American Research 33, no. 3 (2014): 292.

38. Belli, The Country Under My Skin, 212 and 325.

39. Carlos Mejia Godoy, "Lovely Girl of the Sandinista Front." n.d.

40. José Luis Rocha, "Rhetoric, Slogans and Metaphors of the Revolutionary Years," Revista Envío no.

372 (2012), http://www.envio.org.ni/articulo/4557.

41. Jubb, "Love, Family Values and Reconciliation for All," 292. 
42. "In Pictures: Sandinista Revolution Remembered," BBC.com, last modified July 20, 2010, http://www.bbc.com/news/world-latin-america-10689502.

43. Maxine Molyneux, "Mobilization Without Emancipation? Women's Interests, The State, and

Revolution in Nicaragua," Feminist Studies 11, no. 2 (1985): 228.

44. Broadbent et al., Women and Revolution in Nicaragua, 9-10.

45. "Nora Astorga In Her Own Words," 12.

46. Ibid.

47. Broadbent et al., Women and Revolution in Nicaragua, 10.

48. Jaquette, The Women's Movement in Latin America, 2.

49. Molyneux, "Mobilization Without Emancipation?," 245.

50. Kampwirth, "Confronting Adversity with Experience," 142.

51. Molyneux, "Mobilization Without Emancipation?," 228.

$30-34$.

52. Ileana Rodríguez, Women, Guerrillas, and Love. (Minneapolis: University of Minnesota Press, 1996),

53. Ibid., 41.

54. Belli, The Country Under My Skin, 247.

55. Ibid., 263.

56. Molyneux, "Mobilization Without Emancipation?," 229.

57. Randall, Sandino's Daughters Revisited, 133.

58. Molyneux, "Mobilization Without Emancipation?," 229.

59. Randall, Sandino's Daughters, ii.

60. Molyneux, "Mobilization Without Emancipation?," 237.

61. Silke Heumann, "Gender, Sexuality, and Politics: Rethinking the Relationship Between Feminism and Sandinismo in Nicaragua," Social Politics 21, no. 2 (2014): 298.

62. Ibid., 292.

63. Randall, Sandino's Daughters Revisited, 163.

64. Heumann, "Gender, Sexuality, and Politics," 297.

65. Molyneux, "Mobilization Without Emancipation?," 245.

66. Belli, The Country Under My Skin, 288.

67. Broadbent et al., Women and Revolution in Nicaragua, 111.

68. Ibid., 99.

70. Jubb, "Love, Family Values and Reconciliation for All," 292.

71. Broadbent et al., Women and Revolution in Nicaragua, 109.

72. Ibid., 111.

73. Kampwirth, "Confronting Adversity with Experience," 139.

74. Florence E. Babb, After Revolution: Mapping Gender and Cultural Politics in Neoliberal Nicaragua (Austin: University of Texas Press, 2001), 7.

75. Randall, Sandino's Daughters Revisited, 217.

76. Broadbent et al., Women and Revolution in Nicaragua, 32., and Randall, Sandino's Daughters, 137.

77. Jaquette, The Women's Movement in Latin America, 190-191.

78. Molyneux, "Mobilization Without Emancipation?," 229.

79. Keen and Wasserman, A History of Latin America, 485.

80. Babb, After Revolution, 8.

81. Belli, The Country Under My Skin, 303.

82. Molyneux, "Mobilization Without Emancipation?," 241. 
Bibliography

Babb, Florence E. After Revolution: Mapping Gender and Cultural Politics in Neoliberal Nicaragua. Austin: University of Texas Press, 2001.

Belli, Gioconda. The Country Under My Skin. New York: Alfred A. Knopf, 2002.

Broadbent, Lucinda, Helen Collinson, Daphne Davies, Elaine Ginsberg, Clare Nuttall, and Jean Somers. Women and Revolution in Nicaragua. ed. Helen Collinson. London: Zed Books, 1990.

Carr, Irene Campos. "Women's Voices Grow Stronger: Politics and Feminism in Latin America." NWSA Journal 2 No. 3 (1990): 450-463.

Godoy, Carlos Mejia. "Lovely Girl of the Sandinista Front." n.d.

Heumann, Silke. "Gender, Sexuality, and Politics: Rethinking the Relationship Between Feminism and Sandinismo in Nicaragua." Social Politics 21 No. 2 (2014): 290-314.

“In Pictures: Sandinista Revolution Remembered.” BBC.com, last modified July 20, 2010, http://www.bbc.com/news/world-latin-america-10689502.

Jaquette, Jane S. The Women's Movement in Latin America: Feminism and the Transition to Democracy. Winchester: Unwin Hyman, 1989.

Jubb, Nadine. "Love, Family Values and Reconciliation for All, but What about Rights, Justice and Citizenship for Women? The FSLN, the Women's Movement, and Violence Against Women in Nicaragua." Bulletin of Latin American Research 33 No. 3 (2014): 289-304.

Kampwirth, Karen. "Confronting Adversity with Experience: The Emergence of Feminism in Nicaragua." Social Politics 3, no. 2 (1996): 136-159.

Keen, Benjamin, and Mark Wasserman. A History of Latin America. Boston: Houghton Mifflin Company, 1988.

Molyneux, Maxine. "Mobilization Without Emancipation? Women's Interests, The State, and Revolution in Nicaragua". Feminist Studies 11 No. 2 (1985): 227- 254.

“Nora Astorga in Her Own Words.” Revisit Envío, No. 82 (1988).

Randall, Margaret. Sandino's Daughters: Testimonies of Nicaraguan Women in Struggle. Vancouver: New Star Books, 1981.

Randall, Margaret. Sandino's Daughters Revisited: Feminism in Nicaragua. Vancouver: New Star Books, 1994. 
Reif, Linda L. "Women in Latin American Guerrilla Perspectives: A Comparative Perspective." Comparative Politics 8, no. 2 (1986): 147-169.

Rocha, Joé Luis. "Rhetoric, Slogans and Metaphors of the Revolutionary Years." Revista Envío no. 372 (2012), http://www.envio.org.ni/articulo/4557.

Rodríguez, Ileana. Women, Guerrillas, and Love. Minneapolis: University of Minnesota Press, 1996.

Vigal, Ariana E.. "Gender, Difference, and the FSLN Insurrection" in War Echoes: Gender and Militarization in U.S. Latina/o Cultural Production. New Brunswick: Rutgers University Press, 2014. 